\title{
Sri Lankan Rainfall Climate and its Modulation by El Niño and La Niña Episodes
}

\author{
Zeenas Yahiya, Janaki Chandimala, Manjula Siriwardhana and Lareef Zubair
}

Abstract: Seasonal and inter-annual rainfall variations have profound influence on sectors of engineering concern such as water resources, agriculture, energy, fisheries, environment and construction. One of the dominant mechanisms of global inter-annual climate variability is the El Nino-Southern Oscillation (ENSO). ENSO is a shift in the pattern of oceanic warming and atmospheric circulation centered in the Pacific Ocean with implications on the climate across the tropics. Anomalously warm sea surface temperatures in the equatorial Eastern Pacific is referred to as El Nino phase and its cold analogue is referred to as La Niña. Here, the historical relationship of ENSO to Sri Lankan rainfall is described. Ranking both the seasonal Sri Lankan rainfall and its contemporaneous ENSO index shows a modest but significant association in the January to March, May, July to August and October to December periods. El Nino leads to wetter conditions during May, October, November and December and to drier conditions during January, February, March, July and August. Except for January to March the impacts of La Niña are inverse of that for El Niño. The rainfall during this period declines for both El Nino and La Niña. This relationship between rainfall and ENSO during October to December, January to March and July to August are statistically significant. This association can be used to predict the rainfall during the planting phase and the harvesting phase of the Maha (October to March) and during the harvest season of Yala (April to August). Rainfall predictions can be provided 3-6 months in advance based on the availability of ENSO predictions. The predictability has implications for agriculture, irrigation engineering, hydro-electricity generation and demand, construction planning and disaster risk for planning, operational management and policy formulation.

Keywords: Rainfall, ENSO, Predictability, Yala, Maha

\section{Introduction}

The rainfall in Sri Lanka is important as it affects many sectors such as agriculture, water resources, fisheries, infrastructure and tourism and in inducing disasters ([22-29]). The bimodal rainfall over Sri Lanka is related to the pattern of solar radiation forcing the atmosphere around the regions of its 6-10 oN latitude. The seasonal tilt of the earth with respect to the sun is such that solar radiation over the surrounding seas and the ensuing convection is maximized around April to May and October to November. A central mountain massif that approximates an anchor, lies with its arm located along the centre of the southern part of the island. Rainfall in the western part of the island is augmented by orographic influences due to the rapid and moist Westerlies from April to October. Rainfall in the Eastern hill slopes is enhanced due to the North-easterlies from November to March.

On top of the seasonal variation, there are also inter-annual variation changes driven by the variability of the oceanic and land surfaces and volcanic activity. Oceans dominate the earth's surface and atmospheric energy budgets, and the dominant mechanism of tropical interannual variability is related to the variations in the largest Pacific Ocean - the El Nino-Southern Oscillation (ENSO) mechanism.

Zeenas Yahiya BA in Social Sciences. Projects Manager at the Foundation for Environment, Climate and Technology

Janaki Chandimala BSc in Civil Engineering, MSc in Hydrology and Environmental Engineering. Intermediate Research Engineer at the Foundation for Environment, Climate and Teclinology.

Manjula Siriwardhana BSC in Chemical and Process Enguneering. Junior Research Engineer at the Foundation for Evvironment, Climate and Technology.

Eng. (Dr.) Lareef Zubair BSc from Unitersity of Peradeniya. MSc and PhD from Yale University, USA, Associatc Research Scientist at the International Research Institute for Climate and Society (IRI) US, and Principal Scientist at the Foundation for Environment, Climate and Tecinology. 
ENSO is a shift in the pattern of oceanic warming and atmospheric circulation centered in the Pacific Ocean with implications across the tropics that recurs typically 2 to 7 years apart. Anomalously warm sea surface temperatures in the equatorial Eastern Pacific is referred to as El Niño phase and its cold analogue is referred to as La Niña.

The influence of ENSO on the South Asian climate system differs by season: while the summer (June to September) rainfall in Northern India decreases with the El Niño, it increases in Sri Lanka and Southernmost India from October to December ([13], [14], [18]).

Previous analyses of ENSO-rainfall relationships for Sri Lanka have been provided ([13], [3], [11], [15], [16-18], [6], [8], [30]). Many of these analyses were based on meteorological seasons on winddirections which range in duration from two to five months. However, these meteorological seasons do not line up well with the traditional agricultural seasons ([4], [20], [22], [9]), each year predictions are needed [24] for the seasonal planning ("Kanna") meeting which is conducted in March and September.

The predictability of streamflow has been investigated using the principal component regression scheme in a cross validated mode taking the principal components of sea surface temperature (SST) as the predictors [2]. This has resulted in skillful predictions in Yala and Maha seasons. A significantly correlated rainfall and ENSO means higher degree association between the two parameters will thus result in high predictability using the SST predictors.

At present, several forecast centers issue skillful predictions of the seasonal evolution of tropical (SST) six months in advance [5]. Thus relationships between rainfall and ENSO can be exploited to predict seasonal rainfall.

Here, we consider the agricultural season along with the annual cycle of ENSO influence to choose the seasons that give the highest utility and predictability. Note, also that from the point of view of users, it is useful to quantify all ENSO based relationships even when these are weak, as they may have profound implications in their respective sectors. This paper provides an evaluation of the association between ENSO and Sri Lanka rainfall through correlation analysis, composite analysis and ranked rainfall and ENSO indices.

\section{Data and Methods}

\subsection{Rainfall Data:}

The monthly data for 16 observatories were obtained from the Sri Lanka Department of Meteorology from 1869 to 1998 (Fig. 1). A rainfall index for the entire island was constructed by averaging the monthly rainfall for these stations. In addition, regional rainfall indices were constructed by averaging the rainfall of stations falling within climatically homogenous regions that are described in section 3. Basic statistics for rainfall are provided on a seasonal and regional basis (Table 1 and Fig. 2). Rainfall anomaly is the departure of rainfall from its long-term average and ranked rainfall anomalies are presented in table 3 .

\subsection{ENSO Index:}

An ENSO index in common use known as NINO3 had been constructed as the average SST anomaly for the eastern equatorial Pacific Ocean region of $(90 \mathrm{oW}-150 \mathrm{oW}, 5 \mathrm{oS}$ to $5 \mathrm{oN})$ [6]. The ENSO phases are defined as: El Niño (NINO3 > $0.5 \mathrm{oC})$, La Niña $(\mathrm{NINO} 3<0.5 \mathrm{oC})$ and Neutral phases $(-0.50<$ NINO3 $<0.50 \mathrm{C})$ [13], [14].

\subsection{Composite Analysis:}

Composites of rainfall for three regions and all Sri Lanka are shown in Fig. 2, and composites of rainfall are also presented for the El Niño, Neutral and La Niña phases (Fig.3).

\subsection{Correlation Analysis:}

The Pearson correlation coefficient was used to identify relationships between ENSO indices and rainfall [10]. A correlation was taken to be significant when the no-correlation null hypothesis was exceeded with a probability of 95\%.

\section{Climatology}

\subsection{Mean annual cycle:}

The mean annual cycle of rainfall in Sri Lanka is bimodal ([12], [19], [24]), with a major mode from October to December and a subsidiary mode from April to June (Fig. 2). The October to December rainfall coincides with the commencement of the main cultivation season of Maha (October to March). The April to June 
rainfall coincides with the commencement of the subsidiary cultivation seasons of Yala (April to August) [22]. The rainfall peaks coincide with the passage of the Tropical Convergence Zone (TCZ) over the island [17]. Rainfall during these seasons is relatively high throughout the island. During other periods, there is regional variability primarily due to orographic and cyclonic influences.

\subsection{Cyclonic Influences:}

From November to January, storms and cyclones are steered towards North-Eastern Sri Lanka by prevailing North-easterlies and affect the rainfall particularly along the North-Eastern coast.

\subsection{Orographic Influences:}

An anchor shaped central mountain massif runs North-South in Southern Sri Lanka. The rainfall in the Western region is enhanced from April to October due to orographic rainfall on the windward side of this mountain ridge during the South-West monsoon. Similarly, there is enhanced orographic rainfall in the Eastern side from November to February during the North East monsoon [21].

\subsection{Regionalization:}

The character of the annual climatology by region (Fig. 2) confirms that there are distinct rainfall characteristics for each region [12]. The Plains region may be divided between the Northern and Southern lobes. The Western and Eastern region may be further divided into the coastal $(<200 \mathrm{~m})$ and hill $(>200 \mathrm{~m})$ (Fig. 1). This regionalization differs from the demarcation into dry, wet and intermediate zones which is based on the annual total rainfall and does not segregate the island into regions that distinguish the contrasting seasonality in different parts of Sri Lanka due to dominance by different rainfall mechanisms [24], [30]. Accordingly, the "Plains" region includes the stations at Jaffna, Mannar, Anuradapura, Puttalam and Hambantota. The "Eastern" region includes Trincomalee, Batticaloa, Ampara Tank, Badulla and Diyatalawa. The "Western" region includes Kurunegala, Kandy, Nuwara Eliya, Colombo, Ratnapura and Galle (Fig. 2 and Table 1).

\subsection{Seasons:}

Up to the early 20th century, meteorologists demarcated seasons as the North-East monsoon (November to March) and South-West monsoon (April to October). This demarcation was revised so as to introduce two additional intervening seasons termed "Inter-Monsoons"; Since that period, the following seasons have been used in meteorological analysis: December to February, March to April, May to September, and October to November [1]. While, these are useful for analysis of some meteorological properties such as temperature and wind, they do not match well with the agricultural seasons of Maha (October to March) and Yala (April to August).

The consistent ENSO influences for October to December, January to March, April to June and July to August suggests a quarterly breakdown of seasons that correspond to the planting phase and harvest phase of Maha and Yala. Therefore, here we describe the ENSO influence by quarters starting in October.

\section{ENSO-Rainfall Relationships}

Thecompositerainfall isconstructed by averaging rainfall values when only the particular ENSO phase was prevalent.

\subsection{October to December:}

October is the start of the main Maha cultivation season and the entire island gets high rainfall. The Plains region get $60 \%$ of its rainfall during these three months and this percentage drops slightly in the Eastern and Western regions to about $45 \%$ (Table 1 ).

ENSO indices provide strong correlations (Table 2) and the significance of these correlations was at the $99 \%$ level in all regions. During the 35 seasons in which the El Niño phase prevailed, 23 had rainfall in the above normal tercile (Table 3a). Note, that there is a slight drop of predictability in the Eastern Hills region that is subjected to orographic rainfall. Based on these correlation values and contingency table, the rainfall in early Maha has high predictability.

\subsection{January to March:}

This is the harvesting phase of the Maha season and it is generally a dry period in the entire island. The seasonal rainfall has inverse correlations with $\mathrm{NINO} 3$ that was significant at the $5 \%$ level.

The rainfall in all regions shows significant correlations with ENSO save the coastal Eastern region (Table 2). While the overall correlation between NINO3 and rainfall for the entire 
record is modest, an examination of the annual climatology (Fig. 3) shows that the rainfall during La Niña and particularly during El Niño phases is diminished in comparison to that during the Neutral phase. This relationship leads to low correlation values that mask the actual predictability. Of the 43 wettest tercile of seasons, 30 had neutral ENSO conditions (Table $3 b)$.

The diminishment of predictability in the Eastern coast is likely due to cyclonic storms from the Bay of Bengal that pass on to this coast.

\subsection{April to June:}

This is the start of the subsidiary Yala cultivation season and most of the island gets high rainfall. This period accounts for $24 \%$ of the annual islandwide rainfall. The negative rainfall correlations with NINO3 indices are significant at the 5\% level except for the Eastern record (Table 2).

In the last three decades this correlation has dropped to insignificant levels due to a drop of the ENSO influence on the rainfall of April and June but not May (Table 2). Of the 43 seasons that accounts for the wettest tercile, 18 were in the El Niño phase whereas 14 are assumed by chance (table 3c). This is a small tilt of the odds due to ENSO. In contrast to the weak relationship between ENSO and rainfall during the April to June season, the May ENSO-rainfall correlation has strengthened since then to $5 \%$ significance levels. Of the 43 seasons that account for the wettest tercile, 22 were in the El Niño phase (Table 3d).

\subsection{July to August:}

This is the harvest phase of the Yala season and it is generally a dry period in the entire island except in the South-West. September is a transitional month from a dry to a wet period and form and between periods of opposing ENSO influences: the rainfall in the latter half of September has characteristics akin to the October to December season and thus is omitted from this analysis. The July-August rainfall has a NINO3 correlation $(\mathrm{r}=-0.29)$ that is highly significant. Of the 43 seasons that accounts for the wettest tercile, 18 were in the La Niña phase whereas only 14 would be expected by chance (Table $3 \mathrm{e}$ ). Similarly, of the 43 driest tercile of seasons, 18 were coincident with the El Niño phase.

\section{Discussion}

The ENSO rainfall correlation during Yala is greater outside the Western region which garners orographic rainfall in this season. Orographic rainfall and cyclonic storms in Sri Lanka diminish the correlation between ENSO and rainfall. For instance, the Eastern region receives cyclonic storms from the Bay of Bengal and orographic rainfall from November to January: the ENSO correlations are diminished for the Eastern region during this period. Similar The Western region receives orographic rainfall when the westerlies are strongest from July to August and the ENSO correlations are diminished in the Western region.

The predictability based on ENSO for rainfall is robust from October to December. Even while, the predictability is modest for rainfall from January to September, the accumulation of modest influence of ENSO over January to March and July to August leads to profound implications for various sectors. For example, there is reduction of stream flow for Yala during El Niño episodes [24]. The rice cultivation in the Yala (April to August) season is significantly reduced during El Niño period [22]. As the role of regional land surface and Indian Ocean sea surface conditions in modulating the climate is understood, then the predictions scheme presented here based on ENSO is likely to be improved.

\section{Conclusions}

The seasons that show consistent ENSO-rainfall relationships were identified as January-March, May, July-August and October - December. During January to March and July to August, El Niño leads to drier conditions. During May and October to December, El Niño leads to wetter conditions. For La Niña, this relationship was inverted for all seasons except for January to March: the rainfall during both the El Niño and La Niña phases decline. 


\section{References}

1. A.J. Bamford, "Ceylon Rainfall," Quarterly Journal of the Royal Meteorological Society, LXVIII (202), pp. 206-207, 1922.

2. J. Chandimala and L. Zubair, "ENSO based predictions for Water Resources Management in Sri Lanka," Journal of Hydrology, 335, 303312p, 2007.

3. T.K. Fernando, P.M. Jayatillake Banda and L. Chandrapala, "Recent ENSO events in Sri Lanka-A comparative study of the droughts of 1983, 1987 and 1992", Proceedings of the International Symposium on Climate and Life in the Asia Pacific, University of Brunei, Darrusalam, 1995.

4. M. Domroes, "The Agroclimate of Sri Lanka" Franz Steiner Verlag Gmbh: Wiesbaden, 1974.

5. L. Goddard, S.J. Mason, S.E. Zebiak, C.F. Ropelewski, R. Basher and M.A. Cane, "Current approaches to seasonal-to-interannual climate predictions," International Journal of Climatology, 21(9), pp. 1111-1152, 2001.

6. R.P. Kane, "ENSO relationships to the rainfall of Sri Lanka", International Journal of Climatology, 18, pp. 859-871, 1998.

7. A. Kaplan, M.A. Cane, Y. Kushnir, A.C. Clement, Blumenthal, M.B. and Rajagopalan, B. "Analyses of global sea surface temperature: 1856-1991," Journal of Geophysical Research, 103, pp. 18567-18589, 1998.

8. B.A. Malmgren, E.R. Ranatunge, Y. Hayashi and T. Mikami, "Precipitation trends in Sri Lanka since 1870s and relationships to El Niño -Southern Oscillation," International Journal of Climatology, 23 (10), pp. 1235-1252, 2003.

9. T.S.G. Peiris, J. Hansen and L. Zubair, "Use of Seasonal Climate Information to Predict Coconut Production in Sri Lanka," International Journal of Climatology, in press, 2007.

10. W.H. Press, S.A. Teukolosky, W.T. Vetterling and B.P. Flannery, "Numerical Recipes in Fortran," Cambridge University Press, New York, 1992.
11. B.V.R. Punyawardena and N.J. Cherry, "Assessment of the predictability of the seasonal rainfall in Ratnapura using Southern Oscillation and its two extremes," Journal of the National Science Council of Sri Lanka, 27 (3), pp 187-195, 1999.

12. K.M. Puvaneswaram and D.A. Smithson, "Controls on the precipitation distribution in Sri Lanka," Theoretical and Applied Climatology, 47, pp. 105-115, 1993.

13. E.M. Rasmusson and T.H. Carpenter, "The relationship between eastern equatorial Pacific sea surface temperature and rainfall over India and Sri Lanka," Monthly Weather Review, 110, pp. 354-384, 1983

14. C.F. Ropelewski and M.S. Halpert, "Global and Regional scale precipitation patterns associated with the El Niño/Southern Oscillation," Monthly Weather Review, 115, pp. 1606-1626, 1987.

15. W.L. Sumathipala and N.B.P. Punyadeva, "Variation of the Rainfall of Sri Lanka in relation to El Niño," Proceedings of the Annual Sessions of the Institute of Physics, Sri Lanka, Colombo, 1998.

16. R. Suppiah, "Relationship between the southern oscillation and the rainfallSri Lanka," International Journal of Climatology, 9, pp. 601-618, 1989.

17. R. Suppiah, "Spatial and temporal variations in the relationships between the southern oscillation phenomenon and the rainfall of Sri Lanka," International Journal of Climatology, 16, pp. 1391-1407, 1996.

18. R. Suppiah, "Extremes of the southern oscillation phenomenon and the rainfall of Sri Lanka," International Journal of Climatology, 17, pp. 87-101, 1997.

19. G. Thambyahpillay, "The rainfall rhythm in Ceylon," University of Ceylon Review, 12, pp. 224-273, 1954.

20. M.M. Yoshino, I. Kayane and C.M. Madduma Bandara, "Climate, Water and Agriculture in Sri Lanka", Institute of Geoscience, Climatological Notes, Volume 33, University of Tsukuba, Japan, 1983. 
21. L. Zubair, "A dynamical model for orographic rainfall in Sri Lanka," Proceedings of the TROPMET-99, Chennai, Indian Meteorological Society, pp. 269-273, 1999.

22. L. Zubair, "El-Niño -Southern Oscillation influences on rice production in Sri Lanka," International Journal of Climatology, 22, pp. 242-250, 2002a.

23. L. Zubair, "Development of Meteorology in Sri Lanka," Journal of the Institute of Engineers, Sri Lanka, 15 (2), pp. 14-18, 2002 b.

24. L. Zubair, "Sensitivity of Kelani streamflow in Sri Lanka to ENSO," Hydrological Processes, 17 (12), pp. 2439-2448, 2003a.

25. L. Zubair, U. Tennakone, Z. Yahiya, J. Chandimala, and M.R.A. Siraj, "What led to the May 2003 floods?," Journal of the Institute of Engineers, Sri Lanka, XXXVI (3), pp. 51-56, $2003 b$.

26. L. Zubair, Z. Yahiya, J. Ratnayake and A. Somasundera, "Weather and Climate of Sri Lanka and Impacts and Adaptation: A Reference Guide," Natural Resources Management Services, Polgolla, Kandy, 2004.

27. L. Zubair, "Towards Developing Weather and Climate Prediction for Sri Lanka," Journal of the Institute of Engineers, Sri Lanka, XXXVII (2), pp. 53-58, 2004b.

28. L. Zubair, R. Perera and H. Mathrithillake, "Using Climate Information for Mahaweli river basin management," World Water and Environmental Resources Congress, Philadelphia: American Society of Civil Engineers, p378,doi:10.1061/40685 (2003) 378, 2003

29. L. Zubair, R. Perera and Z. Yahiya, "Was the 2002/03 Maha bumper paddy harvest due to El Niño?," Journal of the Institute of Engineers, Sri Lanka, XXXVIII, 4(2), pp. 63-70, 2005.

30. L. Zubair and C.F. Ropelewski, "The strengthening relations between ENSO and North-East Monsoon rainfall over Southern India and Sri Lanka," Journal of Climate, 19 (8), pp. 1567-1575, 2006.

\section{Acknowledgements}

Rainfall data were obtained from the Sri Lanka Department of Meteorology and from the Annual reports submitted by the Colonial Administrators to Great Britain. 


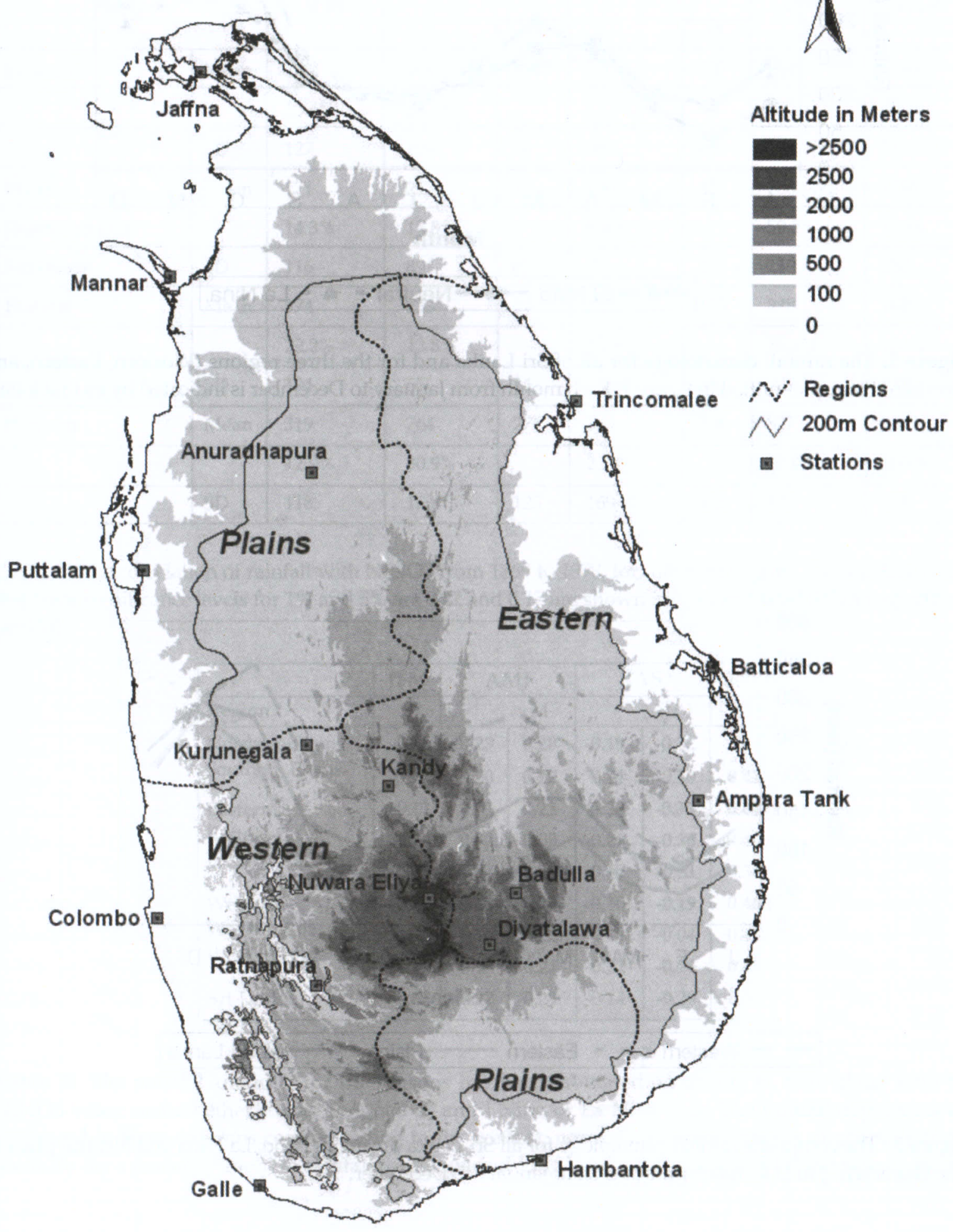

Figure 1: Topography, location of meteorological observatories, and regionalization for Sri Lanka. The $200 \mathrm{~m}$ contour that separates the low areas from the hilly areas is indicated. 


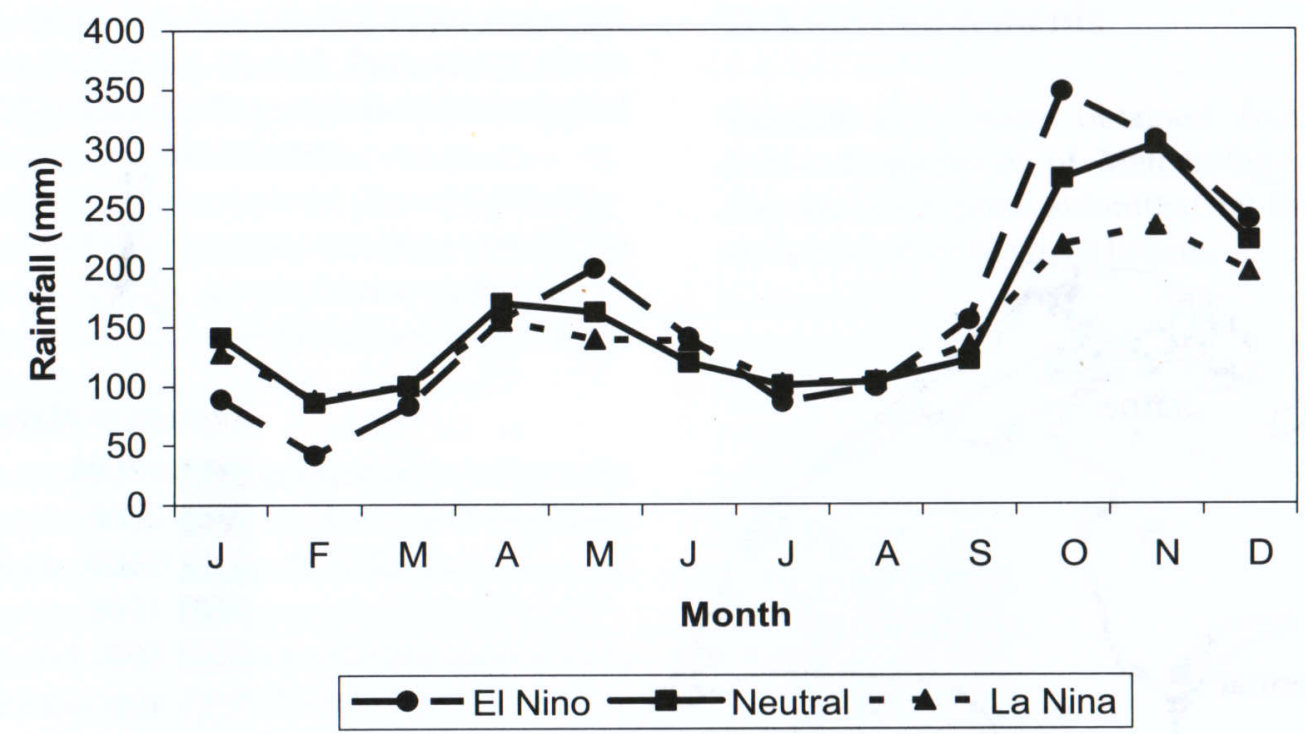

Figure 2: The rainfall climatology for all of Sri Lanka and for the three regions (Western, Eastern, and Northern Plains) identified in figure 1. Each month from January to December is indicated by its first letter.

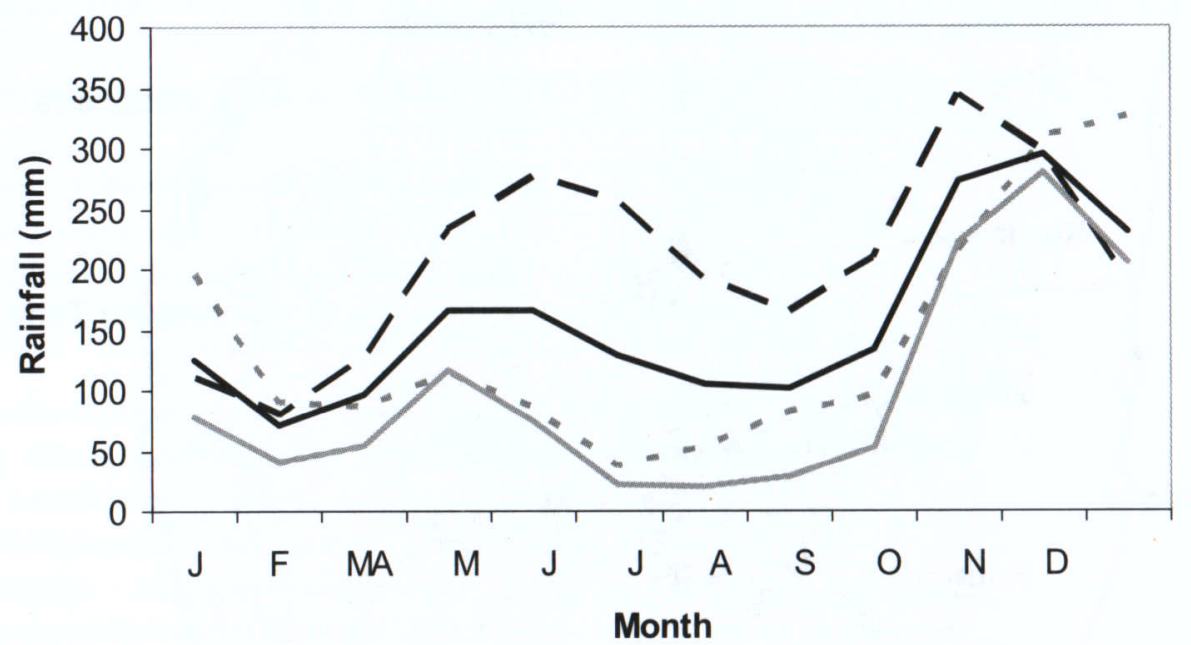

- - Western = - - Eastern —-Plains —All Sri Lanka

Figure 3: The composite rainfall climatology for all Sri Lanka during El Niño, La Niña and Neutral phases. The characters $\mathrm{J}$ to D stands for months from January to December. 
Table 1: The mean, standard deviation (SD) and percent of annual rainfall for quarterly and annual rainfall for all of Sri Lanka and for the three climatic regions are provided in $\mathrm{mm}$. Details are provided for May (M) and July to August (JA) periods as well.

\begin{tabular}{|c|c|c|c|c|c|c|c|c|}
\hline \multicolumn{2}{|c|}{ Region } & \multirow{2}{*}{$\begin{array}{r}\text { JFM } \\
292\end{array}$} & \multicolumn{2}{|c|}{ AMJ } & \multicolumn{2}{|c|}{ JAS } & OND & Total \\
\hline \multirow[t]{3}{*}{ Sri Lanka } & Mean & & 460 & 165 & 340 & 207 & 799 & 1891 \\
\hline & & $15.4 \%$ & $24.3 \%$ & & $17.9 \%$ & & $42.2 \%$ & $100 \%$ \\
\hline & SD & 127 & 101 & 76 & 95 & 67 & 184 & 217 \\
\hline Plains & Mean & 171 & 212 & 74 & 100 & 49 & 706 & 1191 \\
\hline (Northern and & & $14.3 \%$ & $17.8 \%$ & & $8.4 \%$ & & $59.2 \%$ & $100 \%$ \\
\hline Southern) & SD & 116 & 89 & 62 & 58 & 40 & 210 & 230 \\
\hline \multirow[t]{3}{*}{ Eastern } & Mean & 374 & 233 & 84 & 227 & 133 & 848 & 1682 \\
\hline & & $22.2 \%$ & $13.8 \%$ & & $13.5 \%$ & & $50.4 \%$ & $100 \%$ \\
\hline & SD & 194 & 65 & 44 & 78 & 58 & 227 & 282 \\
\hline \multirow[t]{3}{*}{ Western } & Mean & 319 & 764 & 276 & 563 & 356 & 827 & 2473 \\
\hline & & $12.9 \%$ & $30.9 \%$ & & $22.8 \%$ & & $33.4 \%$ & $100 \%$ \\
\hline & SD & 118 & 163 & 125 & 169 & 125 & 180 & 285 \\
\hline
\end{tabular}

Table 2: The correlation of rainfall with NINO3 from 1869 to 1998, for different regions. Correlation values that have significance levels for $1 \%$ and $5 \%$ are 0.22 and 0.17 are shown in bold and bold italics respectively $(n=130)$.

\begin{tabular}{|l|r|r|r|r|r|r|}
\hline & JFM & \multicolumn{2}{|c|}{ AMJ } & \multicolumn{2}{|c|}{ JAS } & OND \\
\hline Region & & \multicolumn{3}{|c|}{ M } & \multicolumn{3}{|c|}{ (JA) } \\
\hline Northern Plains & $-\mathbf{0 . 2 3}$ & $\mathbf{0 . 2 3}$ & $\mathbf{0 . 2 8}$ & $-\mathbf{0 . 1 9}$ & -0.32 & $\mathbf{0 . 4 1}$ \\
Southern Plains & $-\mathbf{0 . 1 7}$ & $\mathbf{0 . 2 0}$ & $\mathbf{0 . 1 7}$ & $\mathbf{0 . 2 4}$ & -0.10 & $\mathbf{0 . 4 1}$ \\
Eastern & -0.11 & 0.11 & $\mathbf{0 . 2 2}$ & $-\mathbf{- 0 . 2 5}$ & -0.37 & 0.44 \\
Eastern Coast & -0.04 & 0.02 & 0.09 & -0.25 & -0.30 & $\mathbf{0 . 4 0}$ \\
Eastern Hills & -0.13 & 0.07 & $\mathbf{0 . 2 3}$ & -0.15 & -0.31 & 0.34 \\
Western & -0.20 & $\mathbf{0 . 1 8}$ & $\mathbf{0 . 2 5}$ & -0.10 & -0.19 & $\mathbf{0 . 4 6}$ \\
Western Coast & $-\mathbf{- 0 . 1 8}$ & $\mathbf{0 . 1 6}$ & $\mathbf{0 . 2 2}$ & 0.11 & -0.04 & $\mathbf{0 . 4 5}$ \\
Western Hill & $-\mathbf{0 . 1 7}$ & $\mathbf{0 . 1 8}$ & $\mathbf{0 . 2 3}$ & $-\mathbf{0 . 2 2}$ & $-\mathbf{- 0 . 2 6}$ & $\mathbf{0 . 4 8}$ \\
Sri Lanka & $\mathbf{- 0 . 1 8}$ & $\mathbf{0 . 2 2}$ & $\mathbf{0 . 2 9}$ & -0.14 & -0.29 & $\mathbf{0 . 5 1}$ \\
\hline
\end{tabular}

Table 3: The rainfall anomaly for the seasons has been tabulated according to rank along with the NINO3 value and whether it was assigned as an El Niño or La Niña year. The rainfall departures are presented in three columns corresponding to the wettest, normal and driest terciles of years. Rainfall anomaly for a period is equal to rainfall for the period-long term average rainfall for the same period. 
Table 3a: Ranked rainfall anomalies for Sri Lanka, corresponding NINO3 index and ENSO condition during the October to December season. (EC - ENSO Condition, E - El Niño, L - La Niña)

\begin{tabular}{|c|c|c|c|c|c|c|c|c|c|c|c|}
\hline \multicolumn{4}{|c|}{ Wettest Tercile of Seasons } & \multicolumn{4}{|c|}{ Normal Tercile of Seasons } & \multicolumn{4}{|c|}{ Driest Tercile of Seasons } \\
\hline Year & Rain $\mathrm{mm}$ & NIN03 & $\mathrm{EC}$ & Year & Rain mm & NIN03 & $\mathrm{EC}$ & Year & Rain $\mathrm{mm}$ & NIN03 & EC \\
\hline 1957 & 232.9 & 1.1 & E & 1932 & 21.6 & 0.0 & & 1871 & -34.8 & -0.1 & \\
\hline 1891 & 167.9 & 0.1 & & 1919 & 17.2 & 0.7 & E & 1926 & -37.1 & 0.0 & \\
\hline 1896 & 143.9 & 1.7 & E & 1982 & 17.2 & 2.8 & E & 1904 & -37.8 & 0.8 & E \\
\hline 1877 & 122.2 & 2.6 & E & 1922 & 15.9 & -0.6 & $\mathrm{~L}$ & 1980 & -38.8 & 0.1 & \\
\hline 1911 & 119.6 & 1.3 & E & 1943 & 14.2 & -0.4 & & 1874 & -39.1 & -1.0 & \\
\hline 1887 & 107.9 & 0.2 & & 1970 & 11.2 & -1.3 & $\mathrm{~L}$ & 1915 & -40.1 & -0.1 & \\
\hline 1884 & 95.9 & 0.8 & E & 1939 & 10.6 & 0.3 & & 1958 & -40.1 & 0.1 & \\
\hline 1902 & 95.2 & 1.6 & E & 1910 & 9.6 & -0.6 & L & 1903 & -41.1 & -0.8 & $\mathrm{~L}$ \\
\hline 1913 & 94.9 & 0.8 & E & 1930 & 7.6 & 1.9 & E & 1934 & -42.4 & -0.1 & \\
\hline 1946 & 93.9 & -0.1 & & 1954 & 7.2 & -0.7 & $\mathrm{~L}$ & 1929 & -45.1 & 0.6 & E \\
\hline 1993 & 89.9 & 0.4 & & 1973 & 7.2 & -1.5 & L & 1968 & -45.8 & 0.5 & E \\
\hline 1997 & 89.2 & 3.5 & E & 1899 & 6.6 & 1.4 & $\mathrm{E}$ & 1876 & -46.1 & 0.4 & \\
\hline 1967 & 86.6 & -0.9 & L & 1961 & 3.2 & -0.4 & & 1996 & -48.8 & -0.4 & \\
\hline 1963 & 85.6 & 1.0 & E & 1990 & 3.2 & 0.2 & & 1989 & -50.4 & -0.1 & \\
\hline 1885 & 81.9 & 0.7 & E & 1880 & 2.6 & 0.4 & & 1901 & -52.1 & -0.1 & \\
\hline 1994 & 70.9 & 1.0 & E & 1900 & -0.8 & 0.4 & & 1908 & -53.1 & -0.9 & \\
\hline 1969 & 68.9 & 1.1 & E & 1936 & -2.8 & 0.2 & & 1937 & -53.1 & -0.3 & \\
\hline 1906 & 66.2 & -0.5 & $\mathrm{~L}$ & 1942 & -4.4 & -1.6 & L & 1870 & -53.4 & -0.8 & L \\
\hline 1931 & 65.2 & -0.6 & L & 1875 & -6.8 & -0.8 & L & 1905 & -54.8 & 1.5 & E \\
\hline 1972 & 65.2 & 2.2 & E & 1953 & -6.8 & 0.4 & & 1981 & -55.1 & 0.1 & \\
\hline 1898 & 61.6 & -0.7 & $\mathrm{~L}$ & 1992 & -7.1 & 0.0 & & 1873 & -57.1 & -0.9 & L \\
\hline 1895 & 59.9 & 0.7 & $\mathrm{E}$ & 1912 & -9.4 & 0.0 & & 1960 & -57.1 & -0.4 & \\
\hline 1914 & 58.2 & 1.3 & $\mathrm{E}$ & 1966 & -9.4 & -0.3 & & 1947 & -61.1 & -0.3 & \\
\hline 1979 & 57.2 & 0.5 & & 1907 & -9.8 & 0.0 & & 1917 & -62.8 & -1.0 & $\mathrm{~L}$ \\
\hline 1944 & 56.2 & -0.6 & L & 1983 & -10.4 & -0.2 & & 1995 & -63.1 & -0.6 & $\mathrm{~L}$ \\
\hline 1923 & 55.6 & 0.9 & E & 1971 & -11.8 & -0.9 & L & 1892 & -63.4 & -1.5 & $\mathrm{~L}$ \\
\hline 1965 & 55.2 & 1.5 & $\mathrm{E}$ & 1985 & -14.4 & -0.5 & $\mathrm{~L}$ & 1924 & -66.1 & -0.7 & L \\
\hline 1882 & 51.9 & -0.6 & $\mathrm{~L}$ & 1956 & -16.4 & -0.7 & L & 1909 & -67.1 & -1.1 & $\mathrm{~L}$ \\
\hline 1935 & 50.6 & 0.2 & & 1975 & -18.1 & -1.2 & L & 1886 & -69.8 & -1.0 & $\mathrm{~L}$ \\
\hline 1925 & 47.9 & 1.3 & E & 1869 & -19.4 & -0.8 & $\mathrm{~L}$ & 1964 & -70.4 & -0.9 & L \\
\hline 1881 & 46.6 & -0.3 & & 1991 & -20.4 & 1.2 & E & 1986 & -71.4 & 1.0 & E \\
\hline 1977 & 44.6 & 0.5 & & 1921 & -20.8 & -0.2 & & 1890 & -71.8 & -0.7 & L \\
\hline 1940 & 41.6 & 1.0 & E & 1894 & -21.1 & -0.3 & & 1952 & -72.1 & -0.3 & \\
\hline 1918 & 38.6 & 1.8 & E & 1872 & -22.4 & -0.9 & L & 1984 & -73.1 & -0.7 & L \\
\hline 1945 & 35.6 & -0.1 & & 1959 & -22.4 & 0.0 & & 1950 & -76.8 & -0.6 & L \\
\hline 1976 & 35.2 & 1.2 & E & 1949 & -23.1 & -1.3 & L & 1955 & -78.8 & -1.5 & L \\
\hline 1888 & 33.9 & 2.0 & E & 1893 & -23.4 & -0.7 & $\mathrm{~L}$ & 1927 & -82.4 & 0.3 & \\
\hline 1978 & 29.6 & 0.0 & & 1987 & -24.4 & 1.4 & E & 1878 & -87.4 & -0.4 & \\
\hline 1920 & 27.6 & -0.1 & & 1962 & -25.4 & -0.6 & L & 1988 & -95.4 & -1.5 & L \\
\hline 1948 & 27.2 & -0.4 & & 1879 & -27.1 & -0.7 & L & 1889 & -97.4 & -1.1 & L \\
\hline 1928 & 23.2 & -0.2 & & 1897 & -30.1 & -0.4 & & 1916 & -102.8 & -1.2 & L \\
\hline 1883 & 22.9 & -0.1 & & 1933 & -30.4 & -1.0 & L & 1974 & -107.8 & -0.4 & \\
\hline \multirow[t]{2}{*}{1941} & 22.6 & 1.5 & E & 1998 & -30.8 & -0.5 & $\mathrm{~L}$ & 1938 & -116.1 & -0.8 & L \\
\hline & & & & 1951 & -33.1 & 0.9 & $\mathrm{E}$ & & & & \\
\hline Total & 43 & E-23 & L-6 & Total & 44 & E-7 & L-19 & Total & 43 & E-5 & L-18 \\
\hline
\end{tabular}


Table 3b: January to March. (EC - ENSO Condition, E - El Niño, L - La Niña)

\begin{tabular}{|c|c|c|c|c|c|c|c|c|c|c|c|}
\hline \multicolumn{4}{|c|}{ Wettest } & \multicolumn{4}{|c|}{ Normal } & \multicolumn{4}{|c|}{ Driest } \\
\hline May Year & \begin{tabular}{|l|} 
Anomaly mm \\
\end{tabular} & NIN03 & EC & May Year & Anomaly $\mathrm{mm}$ & NIN03 & $\mathrm{EC}$ & May Year & Anomaly mm & NIN03 & $\mathrm{EC}$ \\
\hline 1984 & 166.8 & -0.2 & & 1879 & 14.5 & 0.0 & & 1949 & -24.5 & -0.2 & \\
\hline 1913 & 116.2 & 0.2 & & 1893 & 12.2 & -1.3 & $\mathrm{~L}$ & 1914 & -25.5 & 0.8 & E \\
\hline 1934 & 92.2 & -0.5 & L & 1908 & 11.2 & -0.2 & & 1929 & -25.5 & 0.0 & \\
\hline 1986 & 84.5 & -0.4 & & 1928 & 10.5 & 0.0 & & 1900 & -26.5 & 1.3 & E \\
\hline 1938 & 84.2 & -0.5 & $\mathrm{~L}$ & 1965 & 8.2 & -0.3 & & 1956 & -26.8 & -0.5 & L \\
\hline 1917 & 78.2 & -1.3 & $\mathrm{~L}$ & 1967 & 7.8 & -0.2 & & 1968 & -27.8 & -1.1 & $\mathrm{~L}$ \\
\hline 1927 & 77.2 & 0.2 & & 1915 & 7.2 & 1.5 & E & 1987 & -29.2 & 1.3 & E \\
\hline 1925 & 76.2 & -0.5 & L & 1869 & 6.8 & 0.8 & E & 1969 & -29.2 & 0.7 & E \\
\hline 1871 & 71.8 & -0.3 & & 1995 & 6.2 & 0.6 & E & 1932 & -29.5 & 0.1 & \\
\hline 1933 & 71.2 & 0.0 & & 1882 & 6.2 & -0.4 & & 1903 & -29.8 & 0.9 & E \\
\hline 1951 & 67.2 & -0.1 & & 1958 & 5.8 & 1.1 & E & 1910 & -30.2 & -1.0 & $\mathrm{~L}$ \\
\hline 1963 & 65.5 & -0.2 & & 1918 & 5.2 & -0.7 & L & 1894 & -31.2 & -0.7 & L \\
\hline 1944 & 65.2 & -0.1 & & 1943 & 4.8 & -1.1 & L & 1875 & -32.2 & -0.6 & L \\
\hline 1923 & 63.8 & -0.2 & & 1899 & 2.5 & -0.4 & & 1976 & -32.2 & -1.0 & L \\
\hline 1955 & 60.5 & -0.4 & & 1962 & 1.8 & -0.3 & & 1981 & -33.5 & -0.5 & $\mathrm{~L}$ \\
\hline 1960 & 56.2 & 0.1 & & 1946 & 1.2 & -0.3 & & 1885 & -34.5 & 0.5 & E \\
\hline 1954 & 55.2 & 0.0 & & 1966 & -2.8 & 0.8 & E & 1998 & -35.2 & 2.8 & E \\
\hline 1892 & 51.8 & -0.1 & & 1941 & -3.2 & 2.0 & E & 1872 & -35.8 & -0.5 & L \\
\hline 1947 & 51.5 & 0.1 & & 1975 & -3.8 & -0.3 & & 1945 & -36.2 & -0.5 & L \\
\hline 1994 & 47.8 & 0.1 & & 1950 & -3.8 & -1.1 & L & 1911 & -36.2 & -0.7 & $\mathrm{~L}$ \\
\hline 1937 & 44.2 & 0.2 & & 1896 & -5.5 & 0.4 & & 1906 & -36.8 & 0.9 & E \\
\hline 1952 & 38.2 & 0.4 & & 1881 & -7.2 & 0.3 & & 1887 & -37.5 & -0.8 & $\mathrm{~L}$ \\
\hline 1990 & 36.2 & 0.0 & & 1909 & -7.2 & -0.7 & $\mathrm{~L}$ & 1905 & -38.2 & 1.0 & E \\
\hline 1878 & 35.5 & 2.4 & E & 1886 & -9.2 & -0.2 & & 1979 & -38.5 & 0.0 & \\
\hline 1970 & 35.5 & 0.7 & E & 1920 & -10.8 & 1.1 & E & 1959 & -38.8 & 0.0 & \\
\hline 1961 & 32.2 & -0.1 & & 1922 & -10.8 & 0.0 & & 1916 & -39.5 & -0.6 & $\mathrm{~L}$ \\
\hline 1870 & 32.2 & -0.7 & $\mathrm{~L}$ & 1935 & -11.8 & -0.5 & $\mathrm{~L}$ & 1895 & -40.2 & -0.2 & \\
\hline 1924 & 23.5 & 0.7 & E & 1907 & -12.5 & -0.3 & & 1877 & -41.2 & 0.7 & E \\
\hline 1930 & 22.5 & 0.1 & & 1874 & -12.5 & -1.0 & $\mathrm{~L}$ & 1884 & -41.5 & -0.1 & \\
\hline 1964 & 22.2 & 0.1 & & 1873 & -13.5 & -0.8 & L & 1989 & -44.2 & -0.9 & $\mathrm{~L}$ \\
\hline 1936 & 20.8 & 0.2 & & 1988 & -13.8 & 0.5 & E & 1876 & -45.8 & -1.0 & $\mathrm{~L}$ \\
\hline 1891 & 20.8 & 0.1 & & 1978 & -14.8 & 0.3 & & 1974 & -48.2 & -1.0 & L \\
\hline 1921 & 20.8 & -0.7 & $\mathrm{~L}$ & 1926 & -16.8 & 1.3 & E & 1973 & -49.2 & 1.2 & E \\
\hline 1953 & 19.5 & 0.3 & & 1890 & -16.8 & -1.0 & L & 1982 & -51.8 & 0.2 & \\
\hline 1985 & 18.2 & -0.8 & $\mathrm{~L}$ & 1996 & -17.2 & -0.4 & & 1912 & -53.5 & 1.1 & E \\
\hline 1901 & 17.5 & 0.1 & & 1919 & -18.2 & 1.5 & E & 1993 & -55.8 & 0.3 & \\
\hline 1904 & 17.5 & -0.4 & & 1942 & -18.8 & 0.5 & E & 1997 & -59.2 & -0.2 & \\
\hline 1991 & 16.8 & 0.2 & & 1948 & -18.8 & 0.2 & & 1940 & -60.2 & 1.2 & E \\
\hline 1931 & 16.2 & 1.6 & E & 1957 & -19.2 & 0.1 & & 1972 & -64.2 & -0.2 & \\
\hline 1902 & 16.2 & 0.4 & & 1897 & -21.2 & 1.4 & E & 1888 & -65.2 & 0.6 & E \\
\hline 1971 & 15.8 & -1.3 & $\mathrm{~L}$ & 1977 & -22.5 & 0.8 & E & 1980 & -70.5 & 0.3 & \\
\hline 1883 & 15.2 & -0.4 & & 1898 & -22.5 & -0.4 & & 1983 & -74.8 & 2.8 & E \\
\hline \multirow[t]{2}{*}{1880} & 15.2 & -0.6 & $\mathrm{~L}$ & 1889 & -23.5 & 1.7 & E & 1992 & -79.2 & 1.5 & E \\
\hline & & & & 1939 & -23.5 & -0.7 & L & & & & \\
\hline Total & 43 & E- 4 & L-9 & Total & 44 & E-14 & L-10 & Total & 43 & E- 16 & L-15 \\
\hline
\end{tabular}


Table 3c: April to June. (EC - ENSO Condition, E - El Niño, L - La Niña)

\begin{tabular}{|c|c|c|c|c|c|c|c|c|c|c|c|}
\hline \multicolumn{12}{|c|}{ Rainfall Anomalies, NINO3 anomalies } \\
\hline \multicolumn{4}{|c|}{ Wettest Tercile } & \multicolumn{4}{|c|}{ Normal Seasons } & \multicolumn{4}{|c|}{ Driest Seasons } \\
\hline Year & Anomaly & NIN03 & & Year & Anomaly & NIN03 & & Year & Anomaly & NIN03 & \\
\hline 1995 & 82.9 & -0.03 & & 1984 & 16.6 & -0.26 & & 1924 & -17.4 & -0.36 & \\
\hline 1940 & 79.9 & 1.27 & $\mathrm{E}$ & 1962 & 15.6 & -0.45 & & 1937 & -18.4 & -0.03 & \\
\hline 1933 & 75.6 & -0.21 & & 1903 & 14.6 & -0.03 & & 1898 & -19.1 & -0.18 & \\
\hline 1959 & 74.9 & 0.23 & & 1975 & 14.3 & -0.45 & & 1967 & -19.1 & -0.23 & \\
\hline 1930 & 72.3 & 0.50 & E & 1988 & 13.6 & -0.93 & $\mathrm{~L}$ & 1956 & -19.4 & -0.32 & \\
\hline 1891 & 70.6 & 0.60 & E & 1961 & 13.3 & 0.50 & E & 1948 & -21.1 & 0.08 & \\
\hline 1943 & 62.9 & 0.13 & & 1901 & 12.9 & -0.11 & & 1981 & -22.1 & -0.18 & \\
\hline 1888 & 57.9 & 0.74 & E & 1997 & 11.9 & 1.34 & E & 1994 & -23.4 & 0.21 & \\
\hline 1878 & 50.6 & 1.41 & E & 1897 & 9.9 & 0.25 & & 1928 & -25.4 & 0.20 & \\
\hline 1877 & 49.9 & 1.33 & E & 1996 & 8.6 & -0.31 & & 1968 & -25.4 & -0.37 & \\
\hline 1951 & 46.9 & 0.38 & & 1969 & 8.3 & 0.87 & E & 1973 & -25.7 & -0.58 & L \\
\hline 1939 & 43.9 & 0.04 & & 1957 & 4.9 & 0.80 & E & 1980 & -27.1 & 0.42 & \\
\hline 1889 & 42.6 & 0.64 & E & 1944 & 3.9 & 0.18 & & 1869 & -28.1 & -0.02 & \\
\hline 1899 & 41.9 & 0.48 & & 1978 & 2.3 & -0.47 & & 1987 & -28.4 & 1.40 & E \\
\hline 1993 & 40.9 & 1.13 & E & 1949 & 1.6 & 0.06 & & 1921 & -30.7 & -0.31 & \\
\hline 1883 & 39.6 & 0.15 & & 1932 & 0.6 & 0.60 & E & 1909 & -30.7 & -0.39 & \\
\hline 1875 & 38.9 & -0.65 & L & 1985 & -0.1 & -0.53 & $\mathrm{~L}$ & 1881 & -31.7 & 0.28 & \\
\hline 1927 & 36.9 & 0.07 & & 1963 & -0.7 & 0.44 & & 1938 & -32.7 & -0.54 & L \\
\hline 1926 & 35.9 & 0.87 & E & 1922 & -1.4 & 0.10 & & 1913 & -33.4 & -0.10 & \\
\hline 1920 & 35.6 & 0.91 & E & 1902 & -2.4 & 0.90 & E & 1918 & -35.1 & 0.50 & $\mathrm{E}$ \\
\hline 1876 & 33.9 & -0.56 & $\mathrm{~L}$ & 1925 & -3.7 & 0.45 & & 1935 & -36.4 & -0.19 & \\
\hline 1905 & 31.9 & 1.43 & E & 1904 & -4.1 & 0.20 & & 1979 & -37.1 & 0.50 & E \\
\hline 1929 & 31.3 & 0.37 & & 1954 & -4.1 & -0.74 & $\mathrm{~L}$ & 1880 & -37.1 & -0.15 & \\
\hline 1982 & 30.9 & 0.90 & E & 1989 & -4.4 & -0.24 & & 1894 & -38.4 & -0.45 & \\
\hline 1955 & 30.3 & -0.73 & $\mathrm{~L}$ & 1896 & -5.1 & 0.41 & & 1946 & -38.7 & -0.27 & \\
\hline 1942 & 29.3 & -0.05 & & 1970 & -5.4 & -0.24 & & 1884 & -39.1 & 0.41 & \\
\hline 1916 & 27.3 & -0.79 & L & 1998 & -5.7 & 1.22 & E & 1945 & -39.1 & 0.07 & \\
\hline 1974 & 26.3 & 0.03 & & 1965 & -6.1 & 0.70 & E & 1947 & -40.1 & 0.13 & \\
\hline 1952 & 25.3 & 0.10 & & 1890 & -6.4 & -0.52 & L & 1964 & -40.1 & -0.95 & $\mathrm{~L}$ \\
\hline 1900 & 24.6 & 0.94 & E & 1971 & -6.7 & -0.57 & $\mathrm{~L}$ & 1923 & -41.1 & 0.59 & E \\
\hline 1885 & 24.6 & 0.23 & & 1871 & -7.4 & -0.27 & & 1906 & -43.1 & 0.27 & \\
\hline 1887 & 23.9 & -0.24 & & 1934 & -7.7 & 0.22 & & 1914 & -44.4 & 0.77 & E \\
\hline 1873 & 22.9 & -0.49 & & 1892 & -8.4 & -0.49 & & 1910 & -44.4 & -0.94 & L \\
\hline 1972 & 22.3 & 0.77 & E & 1990 & -9.7 & 0.47 & & 1870 & -45.7 & -0.37 & \\
\hline 1912 & 21.6 & 0.47 & & 1895 & -11.1 & 0.13 & & 1986 & -51.4 & 0.03 & \\
\hline 1977 & 21.6 & 0.13 & & 1915 & -11.4 & 1.29 & E & 1911 & -51.4 & -0.25 & \\
\hline 1886 & 21.3 & -0.61 & $\mathrm{~L}$ & 1960 & -12.1 & -0.09 & & 1953 & -52.1 & 0.57 & E \\
\hline 1941 & 20.6 & 1.86 & E & 1907 & -12.4 & 0.22 & & 1950 & -52.1 & -0.77 & $\mathrm{~L}$ \\
\hline 1931 & 19.9 & 0.69 & E & 1872 & -13.1 & -0.61 & $\mathrm{~L}$ & 1966 & -53.4 & -0.06 & \\
\hline 1893 & 17.6 & -1.11 & $\mathrm{~L}$ & 1879 & -13.4 & -0.11 & & 1976 & -57.1 & 0.29 & \\
\hline 1958 & 17.3 & 0.43 & & 1874 & -13.4 & -0.78 & L & 1983 & -59.1 & 2.12 & E \\
\hline 1991 & 16.9 & 0.79 & E & 1919 & -13.7 & 0.88 & E & 1908 & -59.4 & -0.50 & $\mathrm{~L}$ \\
\hline \multirow[t]{2}{*}{1992} & 16.6 & 1.32 & E & 1936 & -14.7 & 0.03 & & 1917 & -63.7 & -0.27 & \\
\hline & & & & 1882 & -15.1 & -0.42 & & & & & \\
\hline Total & 43 & E-18 & L-6 & Total & 44 & E-10 & $\mathrm{L}-7$ & Total & 43 & E- 7 & L- 6 \\
\hline
\end{tabular}


Table 3d: May.. (EC - ENSO Condition, E - El Niño, L - La Niña)

\begin{tabular}{|c|c|c|c|c|c|c|c|c|c|c|c|}
\hline \multicolumn{4}{|c|}{ Wettest } & \multicolumn{4}{|c|}{ Normal } & \multicolumn{4}{|c|}{ Driest } \\
\hline Year & Anomaly & NIN03 & EC & Year & Anomaly & NIN03 & EC & Year & Anomaly & $\begin{array}{l}\text { NIN03 } \\
\end{array}$ & EC \\
\hline 1933 & 250.6 & -0.3 & & 1994 & 23.6 & 0.4 & & 1973 & -45.4 & -0.9 & $\mathrm{~L}$ \\
\hline 1930 & 219.6 & 0.4 & & 1959 & 19.6 & 0.4 & & 1897 & -46.4 & 0.2 & \\
\hline 1891 & 200.6 & 0.7 & E & 1974 & 19.6 & 0.1 & & 1935 & -46.4 & -0.2 & \\
\hline 1943 & 193.6 & 0.4 & & 1912 & 16.6 & 0.5 & E & 1875 & -48.4 & -0.6 & $\mathrm{~L}$ \\
\hline 1926 & 179.6 & 0.9 & E & 1924 & 16.6 & -0.5 & $\mathrm{~L}$ & 1909 & -48.4 & -0.3 & \\
\hline 1940 & 145.6 & 1.4 & E & 1882 & 15.6 & -0.3 & & 1947 & -48.4 & 0.1 & \\
\hline 1936 & 140.6 & 0.1 & & 1879 & 13.6 & -0.1 & & 1906 & -49.4 & 0.2 & \\
\hline 1883 & 125.6 & 0.1 & & 1965 & 12.6 & 1.0 & E & 1900 & -51.4 & 1.0 & E \\
\hline 1972 & 120.6 & 0.8 & E & 1937 & 11.6 & -0.2 & & 1914 & -51.4 & 0.8 & E \\
\hline 1993 & 117.6 & 1.4 & E & 1904 & 6.6 & 0.2 & & 1890 & -54.4 & -0.4 & \\
\hline 1916 & 115.6 & -0.8 & L & 1939 & 2.6 & 0.1 & & 1971 & -56.4 & -0.7 & L \\
\hline 1978 & 108.6 & -0.3 & & 1984 & 2.6 & -0.2 & & 1980 & -56.4 & 0.4 & \\
\hline 1995 & 104.6 & -0.1 & & 1922 & -0.4 & 0.2 & & 1871 & -57.4 & -0.3 & \\
\hline 1927 & 101.6 & 0.2 & & 1970 & -2.4 & -0.2 & & 1986 & -59.4 & 0.0 & \\
\hline 1977 & 101.6 & 0.3 & & 1967 & -4.4 & -0.2 & & 1908 & -62.4 & -0.5 & L \\
\hline 1962 & 96.6 & -0.5 & L & 1985 & -4.4 & -0.5 & $\mathrm{~L}$ & 1988 & -67.4 & -1.0 & $\mathrm{~L}$ \\
\hline 1903 & 95.6 & 0.0 & & 1963 & -7.4 & 0.5 & E & 1892 & -68.4 & -0.4 & \\
\hline 1886 & 80.6 & -0.5 & L & 1915 & -9.4 & 1.3 & E & 1979 & -68.4 & 0.6 & E \\
\hline 1941 & 80.6 & 1.9 & E & 1949 & -9.4 & 0.3 & & 1920 & -69.4 & 1.0 & E \\
\hline 1877 & 77.6 & 1.1 & E & 1954 & -9.4 & -0.8 & $\mathrm{~L}$ & 1934 & -71.4 & 0.2 & \\
\hline 1932 & 74.6 & 0.7 & E & 1981 & -10.4 & 0.0 & & 1948 & -72.4 & 0.1 & \\
\hline 1888 & 65.6 & 0.9 & E & 1885 & -11.4 & 0.2 & & 1907 & -74.4 & 0.2 & \\
\hline 1952 & 64.6 & 0.1 & & 1893 & -12.4 & -1.2 & L & 1872 & -75.4 & -0.7 & L \\
\hline 1969 & 63.6 & 1.1 & & 1918 & -14.4 & 0.6 & E & 1869 & -77.4 & 0.0 & \\
\hline 1876 & 61.6 & -0.5 & $\mathrm{~L}$ & 1942 & -14.4 & 0.1 & & 1968 & -77.4 & -0.6 & $\mathrm{~L}$ \\
\hline 1998 & 61.6 & 1.6 & E & 1989 & -14.4 & -0.2 & & 1870 & -78.4 & -0.4 & \\
\hline 1997 & 60.6 & 1.4 & E & 1874 & -15.4 & -0.7 & L & 1911 & -80.4 & -0.2 & \\
\hline 1889 & 58.6 & 0.7 & E & 1880 & -16.4 & -0.1 & & 1928 & -84.4 & 0.4 & \\
\hline 1873 & 52.6 & -0.4 & & 1884 & -18.4 & 0.5 & E & 1945 & -85.4 & 0.2 & \\
\hline 1992 & 51.6 & 1.7 & E & 1964 & -19.4 & -1.1 & L & 1917 & -86.4 & -0.3 & \\
\hline 1961 & 46.6 & 0.3 & & 1960 & -20.4 & 0.0 & & 1881 & -87.4 & 0.3 & \\
\hline 1919 & 39.6 & 0.9 & E & 1975 & -20.4 & -0.4 & & 1895 & -87.4 & 0.2 & \\
\hline 1951 & 39.6 & 0.3 & & 1901 & -24.4 & -0.1 & & 1921 & -88.4 & -0.3 & \\
\hline 1957 & 39.6 & 0.8 & E & 1983 & -24.4 & 2.3 & E & 1910 & -91.4 & -1.0 & L \\
\hline 1990 & 39.6 & 0.6 & E & 1896 & -26.4 & 0.4 & & 1976 & -96.4 & 0.2 & \\
\hline 1899 & 37.6 & 0.5 & E & 1929 & -27.4 & 0.4 & & 1946 & -97.4 & -0.1 & \\
\hline 1955 & 37.6 & -1.0 & L & 1987 & -27.4 & 1.5 & E & 1938 & -103.4 & -0.5 & $\mathrm{~L}$ \\
\hline 1878 & 35.6 & 1.4 & E & 1925 & -28.4 & 0.3 & & 1956 & -107.4 & -0.3 & \\
\hline 1944 & 34.6 & 0.2 & & 1931 & -28.4 & 0.7 & E & 1996 & -112.4 & -0.3 & \\
\hline 1958 & 34.6 & 0.6 & E & 1887 & -30.4 & -0.1 & & 1923 & -114.4 & 0.7 & E \\
\hline 1982 & 34.6 & 1.0 & E & 1898 & -31.4 & -0.2 & & 1966 & -125.4 & -0.4 & \\
\hline 1991 & 29.6 & 0.9 & E & 1902 & -31.4 & 0.9 & E & 1894 & -137.4 & -0.6 & L \\
\hline \multirow[t]{2}{*}{1905} & 28.6 & 1.5 & E & 1950 & -34.4 & -1.1 & L & 1953 & -151.4 & 0.5 & E \\
\hline & & & & 1913 & -45.4 & -0.2 & & & & & \\
\hline Total & 43 & E- 22 & L-5 & Total & 44 & E-10 & L-7 & Total & 43 & E- 6 & L-10 \\
\hline
\end{tabular}


Table 3e: The ranked rainfall departures for July-August. (EC-ENSO Condition, E-El Niño, L-La Niña)

\begin{tabular}{|c|c|c|c|c|c|c|c|c|c|c|c|}
\hline \multicolumn{4}{|c|}{ Wettest Tercile } & \multicolumn{4}{|c|}{ Normal Seasons } & \multicolumn{4}{|c|}{ Driest Seasons } \\
\hline Year & Anomaly & NIN03 & $\mathrm{EC}$ & Year & Anomaly & NIN03 & EC & Year & Anomaly & NIN03 & EC \\
\hline 1878 & 110.5 & 0.7 & $E$ & 1917 & 9.5 & 0.0 & & 1958 & -22.0 & 0.2 & \\
\hline 1882 & 87.0 & -0.8 & $\mathrm{~L}$ & 1907 & 6.0 & 0.3 & & 1991 & -22.0 & 0.9 & E \\
\hline 1947 & 80.5 & -0.1 & & 1975 & 6.0 & -0.7 & $\mathrm{~L}$ & 1898 & -23.0 & -0.5 & $\mathrm{~L}$ \\
\hline 1998 & 76.0 & 0.0 & & 1939 & 5.5 & 0.2 & & 1987 & -23.5 & 1.6 & E \\
\hline 1909 & 67.0 & -0.4 & & 1959 & 5.5 & -0.5 & $\mathrm{~L}$ & 1993 & -23.5 & 0.3 & \\
\hline 1933 & 66.0 & -0.7 & $\mathrm{~L}$ & 1946 & 4.0 & -0.7 & $\mathrm{~L}$ & 1896 & -24.0 & 1.1 & E \\
\hline 1953 & 64.0 & 0.4 & & 1881 & 3.0 & 0.0 & & 1983 & -25.0 & 1.3 & E \\
\hline 1949 & 63.5 & -0.7 & $\mathrm{~L}$ & 1904 & 3.0 & 0.7 & E & 1872 & -25.5 & -0.6 & $\mathrm{~L}$ \\
\hline 1886 & 62.5 & -0.9 & $\mathrm{~L}$ & 1950 & 1.5 & -0.4 & & 1976 & -25.5 & 0.9 & E \\
\hline 1916 & 59.5 & -1.1 & $\mathrm{~L}$ & 1954 & 1.5 & -0.8 & $\mathrm{~L}$ & 1884 & -26.0 & 0.4 & \\
\hline 1988 & 58.0 & -1.6 & $\mathrm{~L}$ & 1938 & 1.0 & -1.0 & $\mathrm{~L}$ & 1913 & -26.5 & 0.3 & \\
\hline 1900 & 56.0 & 0.7 & E & 1871 & 0.5 & -0.3 & & 1977 & -26.5 & -0.1 & \\
\hline 1915 & 45.0 & 0.8 & $E$ & 1874 & 0.5 & -1.0 & $\mathrm{~L}$ & 1979 & -26.5 & 0.3 & \\
\hline 1931 & 44.0 & -0.2 & & 1984 & 0.5 & -0.4 & & 1982 & -26.5 & 1.1 & E \\
\hline 1923 & 43.0 & 0.7 & E & 1919 & -0.5 & 0.5 & E & 1891 & -27.0 & 0.4 & \\
\hline 1989 & 43.0 & -0.2 & & 1870 & -1.5 & -0.7 & $\mathrm{~L}$ & 1957 & -27.0 & 1.3 & $\mathrm{E}$ \\
\hline 1910 & 41.0 & -0.8 & $\mathrm{~L}$ & 1967 & -2.0 & -0.5 & $\mathrm{~L}$ & 1894 & -28.0 & -0.2 & \\
\hline 1928 & 41.0 & 0.0 & & 1902 & -2.5 & 1.6 & E & 1936 & -28.0 & -0.1 & \\
\hline 1924 & 40.5 & -0.8 & $\mathrm{~L}$ & 1876 & -3.5 & 0.0 & & 1890 & -28.5 & -0.7 & $\mathrm{~L}$ \\
\hline 1996 & 40.5 & -0.1 & & 1941 & -4.0 & 0.6 & & 1922 & -29.0 & -1.0 & $\mathrm{~L}$ \\
\hline 1883 & 37.5 & 0.2 & & 1970 & -4.0 & -1.7 & $\mathrm{~L}$ & 1978 & -29.0 & -0.7 & $\mathrm{~L}$ \\
\hline 1964 & 35.5 & -0.9 & $\mathrm{~L}$ & 1995 & -4.0 & -0.2 & & 1951 & -29.5 & 0.9 & E \\
\hline 1869 & 33.5 & -0.5 & $\mathrm{~L}$ & 1880 & -5.0 & -0.3 & & 1914 & -33.0 & 0.9 & $\mathrm{E}$ \\
\hline 1932 & 33.5 & 0.1 & & 1981 & -6.0 & -0.5 & & 1945 & -33.5 & -0.3 & \\
\hline 1906 & 32.0 & -0.5 & $\mathrm{~L}$ & 1912 & -8.0 & -0.2 & & 1972 & -34.0 & 1.7 & $\mathrm{E}$ \\
\hline 1892 & 30.0 & -0.9 & $\mathrm{~L}$ & 1973 & -9.0 & -1.2 & & 1927 & -34.5 & -0.2 & \\
\hline 1897 & 29.0 & -0.1 & & 1873 & -11.0 & -0.3 & & 1966 & -34.5 & 0.1 & \\
\hline 1960 & 28.0 & 0.0 & & 1877 & -11.0 & 2.0 & E & 1925 & -35.0 & 0.9 & $E$ \\
\hline 1879 & 26.0 & -0.6 & $\mathrm{~L}$ & 1968 & -13.0 & 0.5 & $\mathrm{E}$ & 1952 & -35.0 & -0.4 & \\
\hline 1942 & 24.5 & -1.2 & $\mathrm{~L}$ & 1887 & -13.5 & -0.2 & & 1920 & -35.5 & 0.2 & \\
\hline 1971 & 24.0 & -0.5 & $\mathrm{~L}$ & 1948 & -13.5 & -0.3 & & 1901 & -37.0 & -0.4 & \\
\hline 1903 & 21.0 & -0.5 & $\mathrm{~L}$ & 1985 & -13.5 & -0.7 & $\mathrm{~L}$ & 1986 & -37.5 & 0.2 & \\
\hline 1974 & 20.5 & 0.0 & & 1885 & -14.0 & 0.1 & & 1930 & -38.5 & 1.2 & E \\
\hline 1963 & 19.5 & 1.0 & $E$ & 1955 & -14.5 & -0.5 & $\mathrm{~L}$ & 1918 & -39.0 & 1.1 & $\mathrm{E}$ \\
\hline 1921 & 19.0 & -0.1 & & 1895 & -15.0 & 0.1 & & 1980 & -39.5 & 0.0 & \\
\hline 1937 & 19.0 & -0.4 & & 1994 & -16.0 & -0.2 & & 1940 & -41.0 & 0.7 & $\mathrm{E}$ \\
\hline 1997 & 17.0 & 2.7 & E & 1969 & -17.0 & 0.5 & $\mathrm{E}$ & 1908 & -43.5 & -0.5 & $\mathrm{~L}$ \\
\hline 1962 & 15.5 & -0.1 & & 1893 & -18.0 & -0.8 & $\mathrm{~L}$ & 1911 & -45.5 & 0.5 & $\mathrm{E}$ \\
\hline 1926 & 14.0 & 0.5 & E & 1943 & -18.0 & 0.1 & & 1929 & -46.0 & 0.4 & \\
\hline 1961 & 14.0 & -0.5 & $\mathrm{~L}$ & 1875 & -18.5 & -0.6 & $\mathrm{~L}$ & 1899 & -48.5 & 0.9 & E \\
\hline 1992 & 14.0 & 0.1 & & 1990 & -18.5 & 0.1 & & 1905 & -50.0 & 1.5 & E \\
\hline 1965 & 13.5 & 1.1 & $E$ & 1944 & -19.5 & 0.1 & & 1888 & -57.5 & 0.9 & $\mathrm{E}$ \\
\hline \multirow[t]{2}{*}{1889} & 10.5 & -0.6 & $\mathrm{~L}$ & 1956 & -20.0 & -0.4 & & 1934 & -63.0 & 0.2 & \\
\hline & & & & 1935 & -20.5 & 0.1 & & & & & \\
\hline Total & 43 & E- 8 & L-17 & Total & 43 & E- 6 & L-13 & Total & 43 & E-18 & L-6 \\
\hline
\end{tabular}

